\title{
ASPEK GRAMATIKAL KEAMBIGUITASAN IKLAN KOMERSIAL MEDIA CETAK BALIPOST
}

\author{
Moerdani N Alfonso \\ Program Studi Pendidikan Bahasa Indonesia, Universitas Pendidikan Ganesha \\ Singaraja, Bali, Indonesia
}

Surel: danialfonso778@gmail.com

\begin{tabular}{|c|c|}
\hline \multicolumn{2}{|r|}{ Abstrak } \\
\hline $\begin{array}{l}\text { Kata Kunci: } \\
\text { Gramatikal; Iklan; } \\
\text { Keambiguitasan }\end{array}$ & $\begin{array}{l}\text { Penelitian deskriptif kualitatif ini bertujuan untuk mendeskripsikan aspek gramatikal } \\
\text { keambiguitasan iklan komersial media cetak Balipost. Subjek penelitian ini adalah } \\
\text { iklan komersial media cetak Balipost. Sedangkan objeknya adalah aspek gramatikal } \\
\text { keambiguitasan iklan komersial media cetak Balipost. Data dikumpulkan } \\
\text { menggunakan metode dokumentasi. Teknik analisis data meliputi identifikasi data, } \\
\text { reduksi data, penyajian data, dan penarikan simpulan. Hasil penelitian menunjukan } \\
\text { bahwa iklan komersial media cetak Balipost memiliki keambiguitasan ditinjau } \\
\text { melalui aspek gramatikal. Hal ini dibuktikan dengan ditemukannya kalimat maupun } \\
\text { frasa yang mengandung keambiguan atau kegandaan makna dalam iklan komersial di } \\
\text { media cetak Balipost. }\end{array}$ \\
\hline \multicolumn{2}{|r|}{ Abstract } \\
\hline $\begin{array}{l}\text { Keywords: } \\
\text { Grammatica; } \\
\text { Advertisment; } \\
\text { Ambiguity }\end{array}$ & $\begin{array}{l}\text { This qualitative descriptive study aims to describe the grammatical aspect of } \\
\text { ambiguity in the Balipost print media commercial advertisement. The subject of this } \\
\text { research is Balipost print media commercial advertisement. While the object is the } \\
\text { grammatical aspect of the ambiguity of the Balipost print media commercial } \\
\text { advertisement. Data were collected using the documentation method. Data analysis } \\
\text { techniques include data identification, data reduction, data presentation, and } \\
\text { drawing conclusions. The results of the study show that the Balipost print media } \\
\text { commercial has ambiguity which is reviewed through grammatical aspects. This is } \\
\text { evidenced by the finding of sentences and phrases that contain ambiguity or double } \\
\text { meaning in commercial advertisements in Balipost print media. }\end{array}$ \\
\hline $\begin{array}{l}\text { Diterima/direview/ } \\
\text { dipublikasi }\end{array}$ & 11 Agustus 2021/ 31 Agustus 2021/ 30 September 2021 \\
\hline
\end{tabular}

PENDAHULUAN

Media cetak merupakan media massa yang paling tua dari sekian banyak media massa lainnya. Beberapa dekade lalu, media cetak adalah media massa utama bagi masyarakat untuk memperoleh berita. Sehubungan dengan hal tersebut, Vivian (dalam Swaryputri: 2020) menyatakan bahwa tidak ada sumber berita yang bisa menyamai keluasan dan kedalaman liputan berita koran. Maka dari itu, dapat diketahui bahwa media cetak memiliki pengaruh yang cukup besar dalam kehidupan masyarakat. Media cetak memiliki peranan yang cukup penting, selain sebagai bahan bacaan, media cetak juga memuat berbagai informasi hangat yang berkaitan dengan lingkungan kehidupan masyarakat, selain itu media cetak juga berperan sebagai pelopor dalam perubahan lingkungan kemasyarakatan melalui informasi yang dibagikan dalam media cetak itu sendiri seperti pesan-pesan pendidikan, hiburan yang tentunya dapat dijangkau oleh masyarakat secara luas.

Di Bali, media cetak sangat berperan penting dalam peningkatan pariwisata daerah. Pariwisata merupakan sektor penting dalam pertumbuhan ekonomi masyarakat Bali. Maka dari itu, dibutuhkannya media cetak untuk menyampaikan informasi terkait destinasi wisata yang terdapat di Bali. Dalam hal ini, media cetak yang sering digunakan oleh masyarakat dalam mendapatkan informasi adalah media cetak Balipost. Media cetak Balipost terbit hampir setiap hari, kecuali pada 


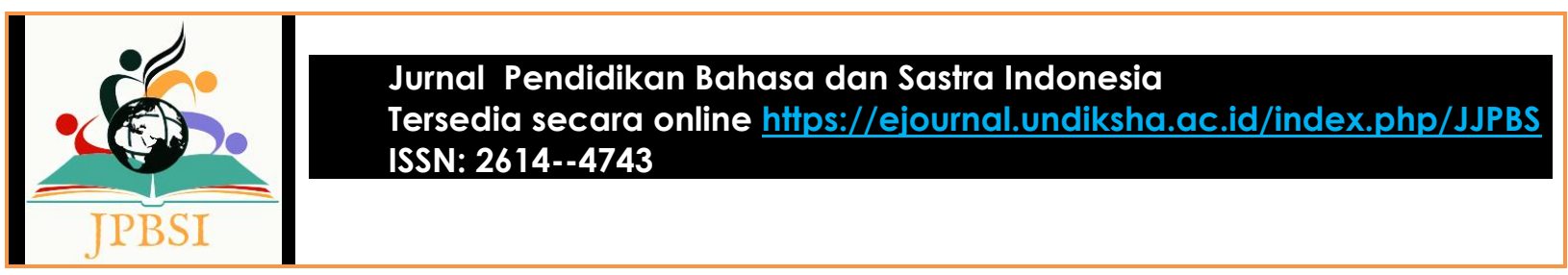

hari-hari libur nasional. Dalam setiap penerbitannya media cetak Balipost memuat beberapa rubrik di antaranya, berita, opini, tajuk rencana, iklan, serta hiburan (cerpen, puisi, komik, dll). Sehubungan dengan rubrik iklan, dalam media cetak Balipost menghadirkan berbagai ragam iklan yang berfungsi sebagai media promosi barang atau jasa kepada masyarakat Bali. Ragam iklan dalam media cetak Balipost di antaranya, iklan komersial, iklan pemberitahuan, iklan display, serta iklan layanan masyarakat. Iklan merupakan pesan atau pemberitahuan tentang jasa atau produk yang ditawarkan, sejalan dengan hal tersebut Alessandri (dalam Masrukhi: 2016) menyatakan, bahwa iklan merupakan sarana untuk mengenalkan merek 'product identity' atau branding image' kepada khalayak ramai. Lebih lanjut, Moriarty (dalam Girsang: 2017) menyatakan bahwa, periklanan dengan media cetak mencakup promosi tercetak di koran, majalah, brosur dan media cetak lainnya.

Sehubungan dengan adanya rubrik iklan, media cetak Balipost membuka penawaran pemasangan iklan yang tentunya dapat difungsikan sebagai media bagi masyarakat untuk menjual produk atau jasanya. Namun, dibalik banyaknya penawaran pemasangan iklan, tentunya masih terdapat kelemahan dari segi kebahasaan ketika media cetak Balipost memuat iklan-iklan tersebut dalam media cetak. Media cetak Balipost tidak memeriksa terlebih dahulu kebahasaan yang digunakan dalam iklan-iklan tersebut. Hal ini dibuktikan dengan banyaknya iklan yang mengandung bahasa yang ambigu. Bahasa ambigu merupakan bahasa yang mengandung makna lebih dari satu atau makna ganda yang dipengaruhi oleh perspektif masyarakat terhadap suatu kata atau frasa yang mengandung ketidakjelasan makna. Ambiguitas atau kegandaan makna sering diartikan sebagai kata yang memiliki makna lebih dari satu atau mendua makna. Chaer (dalam Oktavianti: 2019) menyatakan, bahwa kegandaan makna dalam ambiguitas berasal dari satuan gramatikal yang lebih besar, yaitu frasa atau kalimat, dan terjadi sebagai akibat penafsiran struktur gramatikal. Selain itu, Trismanto (2018) menyatakan bahwa keambiguitasan (ketaksaan) adalah kegandaan arti kalimat yang diucapkan si pembicara sehingga meragukan atau sama sekali tidak dipahami si pendengar.

Keambiguitasan yang paling banyak ditemukan dalam media cetak Balipost yakni yang berkaitan dengan iklan, khususnya iklan komersial. Maka dari itu, peneliti menggunakan iklan komersial dalam media cetak Balipost dalam penelitian ini. Iklan komersial cukup berperan penting dalam keberlangsungan kehidupan masyarakat. Selain sebagai media promosi suatu barang, iklan juga bermanfaat sebagai media informasi, sebagai contoh iklan penjualan sampo yang dapat dimanfaatkan masyarakat untuk mencari tahu manfaat, bahan-bahan, serta zat-zat kimia apa saja yang terdapat dalam sampo tersebut. Tentunya untuk menarik perhatian masyarakat terhadap produk yang ditawarkan, iklan juga perlu menggunakan bahasa yang menarik dan bersifat mengajak atau persuasif. Pada umumnya bahasa iklan mengandung makna-makna tertentu yang merupakan keahlian khusus atau kemampuan khusus dari penggunanya. Sehubungan dengan hal itu, Chaer (dalam Nashiki: 2015) menyatakan, bahwa bahasa iklan merupakan salah satu wujud ragam bahasa jurnalistik yang ragam bahasanya digunakan oleh insan kreatif, dalam hal ini wartawan, untuk penerbitan pers. Berdasarkan pendapat tersebut, dapat diketahui bahwa bahasa iklan merupakan bagian dari ragam jurnalistik yang mempunyai ragam bahasa komunikasi yang khas (dalam artian menggunakan gaya bahasa yang dapat memengaruhi pembaca untuk tertarik terhadap produk yang ditawarkan), yang dipakai untuk mengomunikasikan pesan tentang suatu barang atau jasa yang ditawarkan ke berbagai media, baik itu media cetak maupun media elektronik. Sebenarnya iklan merupakan suatu bentuk penawaran terhadap produk atau jasa. Berdasarkan pemahaman tersebut dapat disimpulkan bahwa iklan merupakan penawaran atau pemberitahuan terkait suatu produk, jasa kepada masyarakat luas yang menggunakan bahasa sebagai alat komunikasi.

Salah satu bentuk keambiguitasan adalah yang dilihat dari aspek gramatikal. Ambiguitas gramatikal timbul dalam tataran pembentukan kata dan kalimat. Djajasudarma (2012: 98) mengatakan bahwa ketaksaan gramatikal muncul pada tataran morfologi dan sintaksis. Dengan demikian, ketaksaan pada tataran ini dapat dilihat dari dua alternatif. Alternatif yang pertama, ketaksaan pada peristiwa pembentukan kata, terlebih khusus pada bidang morfologi yang dapat mengakibatkan 


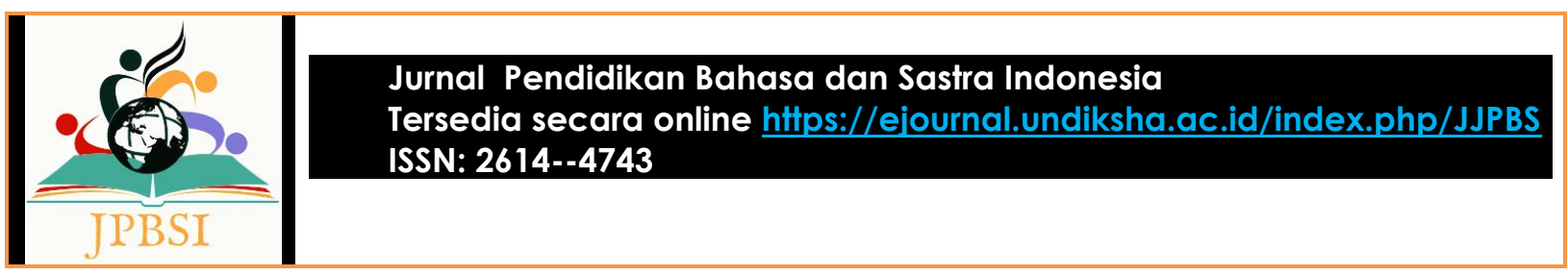

perubahan makna, contohnya prefiks peN, pada kata "pemukul" yang mengandung makna lebih dari satu yaitu yang berarti alat untuk memukul, dan orang yang memukul. Alternatif yang kedua, terletak pada frasa yang mirip. Terlebih khusus pada kombinasi kata yang dapat membuat kegandaan makna. Contohnya pada frasa "orang tua" yang mengandung arti "orang yang lebih tua dan Ibu-bapak".

Salah satu contoh Keambiguitasan yang dilihat dari aspek gramatikal dalam iklan media cetak yakni terdapat dalam sebuah penelitian dengan judul "Ambiguitas makna pada bahasa iklan di harian Gorontalo Post" yang dilakukan oleh Nashiki pada tahun 2015. Dalam penelitian tersebut ditemukan salah satu contoh iklan yang dianalisis oleh Nashiki yang berkaitan dengan ambiguitas iklan. Iklan yang dianalisis adalah iklan kendaraan mobil toyota, khususnya pada slogan "Mau beli mobil..?? Pilih Toyota Saja". Nashiki menjelaskan bahwa dalam slogan iklan mobil toyota tersebut terkandung dua makna yang terkesan membingungkan masyarakat pembaca. Makna yang terkandung dalam slogan iklan mobil toyota tersebut, yakni makna bebas konteks dan makna terikat konteks. Makna bebas konteks dalam slogan iklan tersebut, yakni "jika ingin membeli mobil, pilih toyota saja", namun makna tersebut juga masih memiliki keraguan yaitu pembuat iklan tidak menjelaskan terkait tipe apa saja yang tergolong dalam mobil toyota. Lalu, makna terikat konteks dalam slogan tersebut, yakni "mobil toyota dapat menjadi salah satu pilihan bagi orang yang ingin membeli mobil". Dengan adanya analisis tersebut maka dapat dipastikan bahwa iklan juga penting untuk dianalisis terkait kejelasan maknanya, agar masyarakat dapat memahami informasi yang disampaikan dalam iklan secara akurat dan jelas.

\section{METODE PENELITIAN}

Rancangan penelitian yang digunakan dalam penelitian ini adalah deskriptif kualitatif. Sugiyono (2012: 1) menyatakan bahwa metode penelitian kualitatif sering disebut metode penelitian naturalistik karena penelitiannya dilakukan pada kondisi yang alamiah. Rancangan deskriptif kualitatif digunakan karena penelitian ini menggambarkan dan menginterpretasikan objek berupa ambiguitas gramatikal dalam iklan komersial media cetak Balipost.

Jenis data yang digunakan dalam penelitian ini adalah jenis data kualitatif terkait ambiguitas iklan komersial media cetak Balipost. Data yang digunakan dalam penelitian ini bersumber dari subjek penelitian. Subjek penelitian yang digunakan dalam penelitian ini adalah iklan komersial media cetak Balipost. Sedangkan objek penelitian dalam penelitian ini adalah keambiguitasan iklan komersial media cetak Balipost dan relevansinya terhadap pembelajaran teks iklan di SMP.

Metode yang digunakan oleh peneliti dalam penelitian ini adalah metode dokumentasi dan wawancara. Penggunaan metode dokumentasi dalam penelitian ini dikarenakan peneliti akan meneliti dokumen berupa iklan komersial dalam media cetak Balipost. Data yang kemudian akan diperoleh oleh peneliti dalam penelitian ini, yakni ambiguitas iklan media cetak Balipost pada aspek gramatikal.

Teknik analisis data yang penulis gunakan dalam penelitian ini adalah teknik analisis data deskriptif kualitatif. Teknik analisis data deskriptif kualitatif merupakan teknik analisis dengan cara menginterpretasi data menggunakan kata-kata. Data yang dianalisis merupakan data hasil dokumentasi yang telah penulis kumpulkan sebelumnya. Teknik analisis data yang dilakukan terbagi menjadi beberapa bagian sesuai dengan masalah penelitian. Maka berdasarkan pemahaman tersebut, berikut adalah teknik analisis data yang peneliti lakukan dalam penelitian ini yang merupakan adopsi dari teknik analisis data menurut Miles dan Huberman.

\section{HASIL DAN PEMBAHASAN}

Hasil penelitian "Aspek Gramatikal Iklan Komersial Media Cetak Balipost” diperoleh dari data hasil dokumentasi. Subjek penelitian ini adalah iklan komersial dalam media cetak. Media cetak Balipost digunakan untuk memperoleh data. Dalam media cetak Balipost yang diteliti, ditemukan keambiguitasan aspek gramatikal yang telah terdokumentasi yakni sebanyak 5 data, yang diuraikan sebagai berikut. 


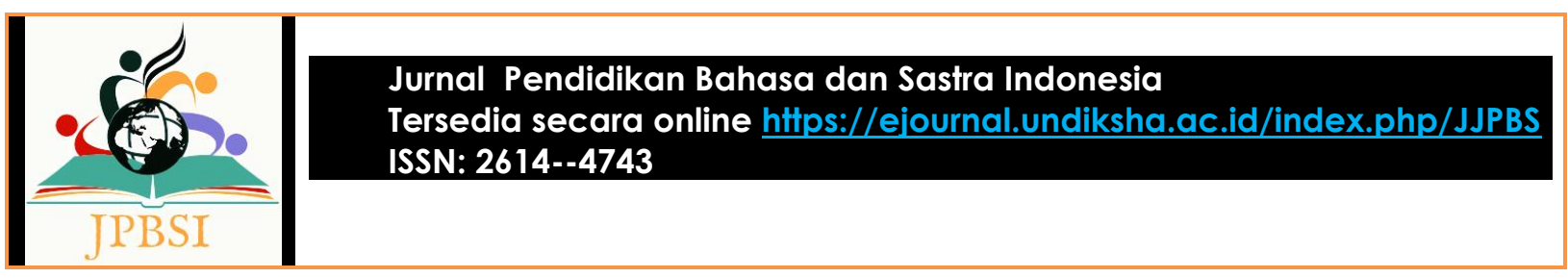

Keambiguitasan pada aspek gramatikal yang pertama terdapat dalam Sebuah iklan komersial berjudul "Rebut Pasar Jepang". Iklan komersial berjudul "Rebut Pasar Jepang" (Data 1 Edisi 8 September 2019) dapat ditemukan dalam media cetak Balipost, dikarenakan iklan tersebut selalu muncul dalam media cetak Balipost dalam setiap penerbitannya. Iklan yang membicarakan tentang promosi barang atau jasa menggunakan bahasa Jepang secara sekilas tampak baik-baik saja, namun ketika diamati secara saksama, iklan tersebut mengandung bahasa yang ambigu. keambiguitasan yang ditemukan dalam dalam iklan tersebut terletak pada judul dari iklan itu sendiri yakni "Rebut Pasar Jepang". Terdapat dua makna yang ditemukan dalam kalimat tersebut. Pertama, "Rebut Pasar Jepang" kalimat tersebut mengandung makna melakukan promosi barang atau jasa menggunakan bahasa Jepang agar dapat bersaing dengan pasar di negara Jepang. Kalimat dalam iklan tersebut berusaha menarik minat pembaca yang berasal dari negara Jepang atau merupakan keturunan bangsa Jepang yang memiliki niat membuka usaha di negara Indonesia. Tujuan dibuatnya iklan tersebut adalah untuk membantu orang berdarah Jepang dalam mengembangkan usahanya di negara rantau agar mampu melebihi atau setara dengan pasar di negara asalnya. Kedua, "Rebut Pasar Jepang" kalimat tersebut mengandung makna melakukan sebuah usaha dengan cara merebut pasarnya secara langsung. Bahasa iklan tersebut secara tidak langsung mencoba menggiring pembaca untuk melakukan sebuah usaha dengan cara yang negatif yakni dengan merebut pasar Jepang secara langsung, maksudnya adalah seorang pelaku usaha membuat sebuah usaha dengan cara menjiplak atau meniru usaha dari negara Jepang kemudian menjadikan usaha tersebut sebagai miliknya demi keuntungannya sendiri.

Ditemukannya keambiguitasan dalam iklan tersebut dikarenakan iklan tersebut memiliki konteks yang tidak lengkap dan kurang jelas. Iklan tersebut semata-mata hanya menjelaskan mengenai beriklan dan melakukan promosi menggunakan bahasa Jepang. Hal tersebutlah yang kemudian membuat pembaca kebingungan akan pesan sebenarnya yang ingin disampaikan oleh pembuat iklan tersebut. keambiguitasan dalam iklan tersebut dapat dihindari jika jika pembuat iklan menjelaskan konteks dari iklan tersebut secara jelas, seperti menambahkan tujuan dari iklan tersebut. Iklan tersebut dapat dituliskan seperti "Rebut Pasar Jepang 'bersaing dengan pasar Jepang dengan cara beriklan dan promosi menggunakan bahasa Jepang untuk orang Jepang"'.

Selain data 1, peneliti juga menemukan makna ambigu pada iklan media cetak Balipost. Makna ambigu yang dimaksud seperti pada iklan "Promo Medika Hospital" (Data 2 Edisi 8 September 2019).Iklan yang satu ini kemunculannya juga sudah tidak asing lagi dalam media cetak Balipost. Iklan yang menjelaskan mengenai promo dalam sebuah institusi rumah sakit ini telah ditemukan keambiguitasan dalam penulisan kalimatnya. keambiguitasan yang ditemukan dalam iklan tersebut berbunyi "Promo Kartini Dapatkan Diskon Untuk Paket Kartini". Kalimat tersebut jika dilihat secara sepintas maka tidak ditemukan masalah dalam penulisannya, namun ketika diperhatikan secara teliti, dalam kalimat tersebut ditemukan keambiguitasan atau makna ganda tepatnya pada frasa "Promo Kartini". Pertama, frasa "Promo Kartini" mengandung makna menyediakan promo atau diskon pada hari kartini. Makna frasa tersebut menjelaskan mengenai penyediaan diskon yang disediakan oleh "Prima Medika Hospital" untuk mengenang hari kelahiran Ibu Kartini yang jatuh pada tanggal 21 April. Promo yang disediakan berupa "Pemeriksaan Dokter Umum, Pap Smear, USG Mammae, Urin Rutin, Hematologi Rutin" yang diturunkan sebanyak 20\% dalam setiap pemeriksaannya. Promo tersebut hanya bisa didapatkan jika melakukan pemeriksaan pada hari Kartini. Kedua, frasa "Promo Kartini" mengandung makna menyediakan promo khusus bagi pasien yang bernama Kartini. Makna tersebut secara tidak langsung masih memiliki hubungan dengan makna yang pertama, yakni untuk mengenang hari Kartini, pihak "Prima Medika Hospital" menyediakan promo untuk mengurangi biaya pemeriksaan kesehatan bagi para pasiennya yang bernama Kartini. Jika makna sebenarnya dari iklan tersebut seperti ini, maka pihak rumah sakit tersebut secara tidak langsung telah melakukan tindakan diskriminatif bagi pasien lainnnya yang bukan bernama Kartini yang kebetulan akan melakukan pemeriksaan kesehatan pada hari Kartini. 


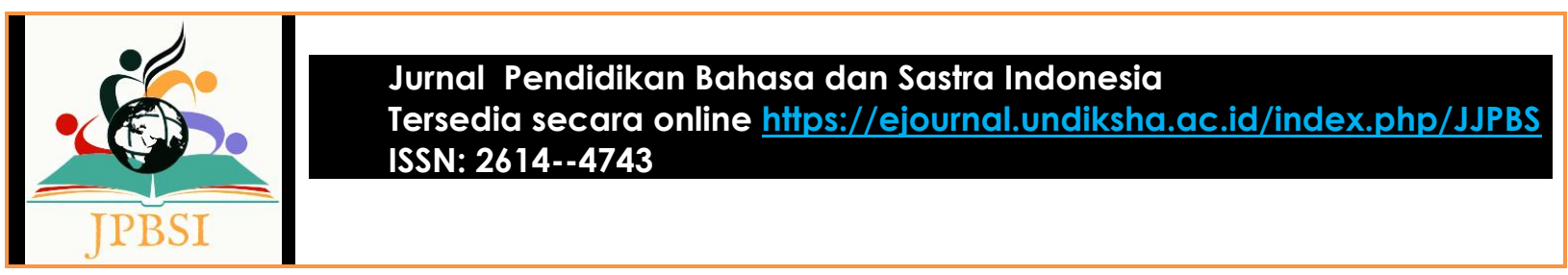

Keambiguitasan yang ditemukan dalam iklan tersebut terjadi akibat ketidakjelasan konteks yang seharusnya menyertai frasa tersebut sehingga menimbulkan multitafsir dari pembacanya. Dalam penulisannya iklan tersebut seharusnya menjelaskan secara menyeluruh terkait promo yang diberikan dan juga menjelaskan mengenai sasaran dari promo tersebut, sehingga masyarakat pembaca memahami maksud dibuatnya iklan tersebut. Iklan tersebut seharusnya ditulis seperti "Promo Kartini, dapatkan diskon untuk mengenang hari Kartini" jika sasaran diskonnya untuk seluruh masyarakat yang melakukan pemeriksaan pada hari Kartini, dan "Promo Kartini, dapatkan diskon untuk masyarakat yang bernama Kartini" jika sasarannya adalah masyarakat yang bernama Kartini.

Keambiguitasan lain ditemukan dalam iklan "Dapur Prima (Pusat Perlengkapan dapur dan Rumah Tangga" (Data 3 Edisi 2 September 2019). Iklan pusat perbelanjaan memang sudah tidak asing lagi didengar, baik iklan yang disaksikan melalui kanal televisi maupun melalui media cetak. Iklan pusat perbelanjaan yang ditemukan dalam media cetak kali ini berjudul "Dapur Prima (Pusat Perlengkapan Dapur dan Rumah Tangga)". Jika dilihat dari judulnya, maka dapat dipastikan bahwa iklan tersebut menjelaskan mengenai tersedianya perlengkapan-perlengkapan yang digunakan dalam kehidupan berumah-tangga. Perlengkapan-perlengkapan tersebut dapat ditemukan di "Dapur Prima". Judul dari iklan tersebut ditemukan keambiguitasan yang menyebabkan kegandaan penafsiran, judul tersebut ditemukan frasa yang terkesan ambigu yakni frasa "Rumah Tangga dan Dapur Prima". Pertama, Judul iklan "Dapur Prima: Pusat Perlengkapan Dapur dan Rumah Tangga" mengandung keambiguitasan dalam penulisan kalimatnya. keambiguitasan yang pertama terdapat pada frasa "Dapur Prima". Makna yang terkandung dalam frasa tersebut terdapat dua makna yakni, makna yang pertama berarti dapur dari seorang bernama "Prima" yang memiliki berbagai perlengkapan dapur dan kebutuhan berumah-tangga. Makna pertama yang diketahui dalam frasa tersebut dapat membuat masyarakat mengetahui bahwa seorang yang bernama Prima mencoba untuk mengiklankan dapurnya, yang tujuannya adalah untuk menyewakan perlengkapan dapurnya kepada masyarakat secara luas. Makna yang kedua dari frasa "Dapur Prima" berarti sebuah toko atau perusahaan yang dinamakan prima. Toko tersebut menjual berbagai kebutuhan berumah-tangga, seperti perlengkapan dapur dan kebutuhan rumah tangga lainnya. Kedua, selain frasa "Dapur Prima", ditemukan juga frasa lain yang mengandung bahasa keambiguitasan dalam judul iklan tersebut yakni frasa "Rumah Tangga". Frasa "Rumah Tangga" dalam iklan tersebut mengandung dua makna, yaitu makna yang pertama dari frasa "Rumah Tangga" berarti kehidupan berkeluarga dan makna yang kedua dari frasa "Rumah Tangga" berarti rumah yang memiliki tangga.

Selain frasa yang mengandung keambiguitasan, keseluruhan dari iklan tersebut juga mengandung ketidakjelasan makna, dikarenakan dalam iklan tersebut tidak dijelaskan mengenai perlengkapan dapur apa saja yang disediakan atau yang dijual oleh "Dapur Prima". Selain itu, penjelasan dalam iklan tersebut juga perlu memperjelas konteks dalam iklan tersebut. Perlu dijelaskan perlengkapan apa saja yang disediakan, kemudian apakah perlengkapan itu dijual atau disewakan. Maka dari itu penulisan judul iklan tersebut seharusnya seperti "Dapur Prima : Pusat Perbelanjaan Perlengkapan Dapur dan Kebutuhan Berumah-tangga.

Keambiguitasan lainnya terdapat pada Iklan "Mpoin (Tangki Air dan Kimia)” (Data 4 Edisi 2 November 2020). Iklan tersebut merupakan sebuah iklan yang dimuat dalam media cetak Balipost pada tanggal 2 November 2020. Iklan tersebut menyajikan iklan penjualan sebuah produk tangki air. Iklan tersebut bertujuan untuk menyajikan sebuah produk tangki air yang dapat difungsikan sebagai tempat menampung air. Dalam pemuatannya dalam media cetak, ditemukan kalimat yang mengandung keambiguitasan atau kegandaan makna. Kalimat tersebut adalah kalimat "Tangki Air Bebas Kuras". Pertama, kalimat "Tangki Air Bebas Kuras" mengandung makna sebuah tangki air yang bisa dikuras kapan saja dan dimana saja. Berdasarkan makna tersebut maka dapat diketahui bahwa iklan tersebut menjual produk tangki air yang cukup besar sehingga bisa dan mudah untuk dikuras saat kotor. Iklan tersebut menyasar masyarakat yang mengalami kesusahan saat menguras tangki air dikarenakan fisik tangki air yang terlalu kecil. Berdasarkan permasalahan masyarakat, iklan 


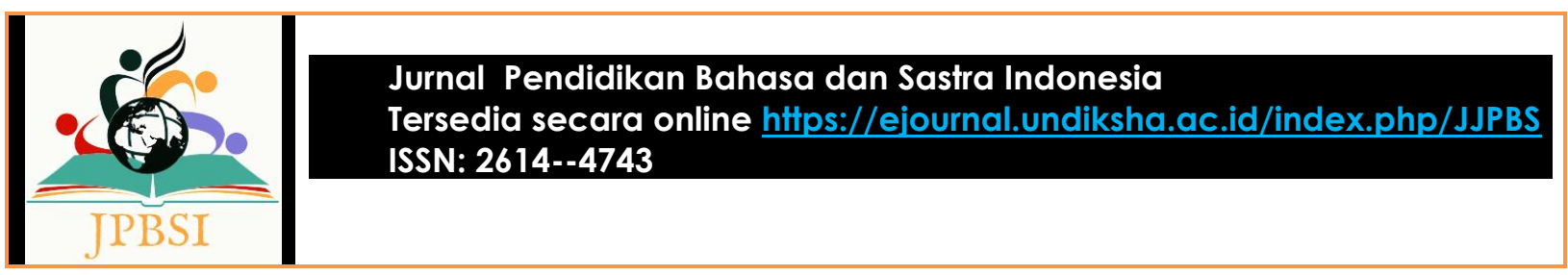

tersebut pun menyajikan solusi berupa produk bernama "Mpoin: Tangki Air Bebas Kuras". Kedua, kalimat "Tangki Air Bebas Kuras" mengandung makna sebuah tangki air yang tidak perlu dikuras. Berdasarkan makna tersebut dapat diketahui bahwa iklan tersebut menyajikan sebuah produk tangki air yang tidak perlu dikuras. Maksud dari tidak perlu dikuras adalah tangki tersebut telah mengandung zat-zat kimia yang dapat membunuh kuman dalam air sehingga pembeli produk tersebut tidak perlu khawatir dengan kondisi airnya yang disimpan dalam tangki air. Sasaran dari iklan tersebut adalah masyarakat yang mengalami masalah air yang tidak dapat bertahan lama jika disimpan dalam tangki air. Maka dari itu iklan tersebut menyajikan solusinya yaitu tangki air yang tidak perlu dikuras.

Berdasarkan makna yang ditemukan dalam kalimat iklan tersebut maka dapat dipastikan bahwa iklan tersebut mengandung kalimat keambiguitasan yang dapat memengaruhi perspektif masyarakat pembacanya. Selain keambiguitasan yang sudah dijelaskan diatas, ditemukan juga keambiguitasan dalam judul iklan tersebut yakni "Tangki Air dan Kimia" dalam kalimat tersebut ditemukan ketidakjelasan makna yakni tidak dijelaskan mengenai apa yang sebenarnya dijual dalam iklan tersebut apakah iklan tersebut menjual "Tangki Air dan Bahan-bahan Kimia" ataukah "Tangki Air yang Mengandung Bahan Kimia". Jika hanya dilihat secara sepintas tentu akan menimbulkan kebingungan dalam judul iklan tersebut sehingga memunculkan multiperspektif dari masyarakat. keambiguitasan dalam iklan tersebut dapat dihindari dengan cara menjelaskan konteks iklan secara jelas, misalnya "menyediakan tangki air berbahan kimia".

Selanjutnya, Iklan "PVC Panel Upton" (Data 5 Edisi 16 November 2020) merupakan iklan penjualan panel yang dapat difungsikan sebagai hiasan dalam rumah. Iklan tersebut ditujukan bagi masyarakat yang ingin mempercantik rumahnya dengan desain panel yang cantik. Untuk menarik minat masyarakat, iklan tersebut dimuat dan dipromosikan dalam media cetak Balipost. Dalam pemuatannya di media cetak, ditemukan kalimat yang ambigu atau kalimat yang mengandung multiperspektif dalam iklan tersebut. kalimat yang mengandung multiperspektif dalam iklan tersebut ditemukan dalam kalimat "Kini Hadir di Kota Terdekat Anda Denpasar dan Singaraja". Kalimat tersebut dikatakan ambigu dikarenakan kalimat tersebut mengandung dua makna. Pertama, kalimat "Kini Hadir di Kota Terdekat Anda Denpasar dan Singaraja" mengandung makna produk tersebut dapat ditemukan di kota Denpasar dan Singaraja. Berdasarkan makna tersebut maka dapat diketahui bahwa produk tersebut telah diperjualbelikan di kota Denpasar dan Singaraja. Iklan tersebut dibuat dengan tujuan agar pembacanya tahu bahwa produk tersebut dijual di kota Denpasar dan Singaraja, sehingga masyarakat pembaca bisa segera menuju ke lokasi produk tersebut dijual di kota Denpasar dan Singaraja. Kedua, kalimat "Kini Hadir di Kota Terdekat Anda Denpasar dan Singaraja" mengandung makna produk tersebut mudah ditemukan di kota yang dekat dengan Denpasar dan Singaraja. Iklan tersebut mencoba menyampaikan kepada pembaca bahwa produk yang dijual sudah dapat ditemukan di kota yang dekat dengan kota Denpasar dan Singaraja seperti kota Gianyar, Kuta, Bedugul, dan lain sebagainya. Iklan tersebut dibuat agar masyarakat tahu bahwa produk tersebut telah tersebut dibeberapa wilayah kota, sehingga masyarakat tidak perlu lagi menuju ke Denpasar dan Singaraja untuk memeroleh produk tersebut.

Dengan mengetahui kedua makna yang ditemukan dalam kalimat iklan tersebut, maka dapat diketahui bahwa iklan tersebut mengandung keambiguitasan yang dapat memengaruhi interpretasi pembaca. keambiguitasan yang ditemukan tersebut disebabkan oleh penggunaan kata yang tidak tepat serta konteks yang tidak jelas. keambiguitasan tersebut dapat dihindari dengan menggunakan katakata yang tepat atau menjelaskan konteks secara jelas. Agar tidak terkesan ambigu, kalimat tersebut seharusnya dituliskan seperti berikut "PVC Panel Upton: Kini Hadir di Kota Denpasar dan Singaraja".

Berdasarkan hasil penelitian analisis keambiguitasan aspek gramatikal iklan komersial dalam media cetak Balipost, maka dapat diidentifikasi temuan dalam penelitian ini, yakni terdapat 5 data yang menunjukan keambiguitasan aspek gramatikal dalam iklan komersial media cetak Balipost. Temuan 5 data yang tergolong keambiguitasan aspek gramatikal tersebut dapat dilihat dari dua alternatif. Hal ini sejalan dengan yang dinyatakan oleh Djajasudarma (2012: 98) bahwa dengan 


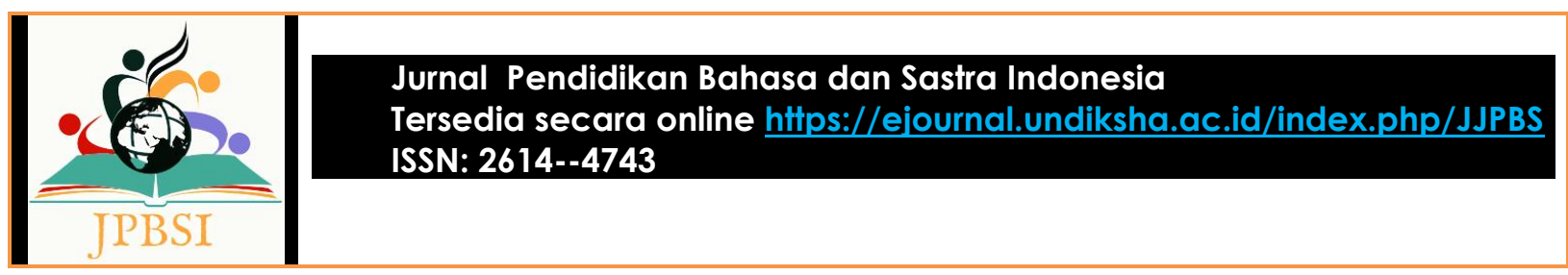

demikian, ketaksaan atau keambiguitasan dapat dilihat dari dua alternatif, yakni alternatif yang pertama terletak dalam peristiwa pembentukan kata dan alternatif yang kedua terletak pada frasa yang mirip. Selain itu, Wijana (2008) juga menyatakan bahwa keambiguitasan pada tingkat gramatikal terjadi karena proses penggabungan satuan-satuan lingual menurut sistem bahasa tertentu. Sejalan dengan kedua pernyataan tersebut, maka dalam iklan komersial media cetak Balipost pun terdapat kalimat maupun frasa-frasa yang bersifat ambigu yang kemudian dapat memengaruhi interpretasi pembaca iklan-iklan tersebut, hal ini sejalan dengan pernyataan dari Chaer (dalam Oktavianti: 2019) yang menyatakan, bahwa kegandaan makna dalam ambiguitas berasal dari satuan gramatikal yang lebih besar, yaitu frasa atau kalimat, dan terjadi sebagai akibat penafsiran struktur gramatikal. Berdasarkan kedua pendapat tersebut maka dapat disimpulkan bahwa keambiguitasan aspek garamatikal dapat dilihat dari bentuk frasa maupun kalimat. Bentuk keambiguitasan aspek gramatikal yang paling banyak ditemukan dalam iklan media cetak Balipost adalah yang berbentuk frasa. Keambiguitasan pada aspek gramatikal yang berbentuk frasa terjadi sebagai akibat dari kombinasi kata yang tidak tepat. Sejalan dengan hal tersebut, Djajasudarma (1993: 55) menyatakan bahwa, tiap kata yang berbentuk frasa sebenarnya sudah tampak jelas, namun kombinasi dari kata-kata tersebut mengakibatkan maknanya dapat diartikan lebih dari satu pengertian. Data berikut adalah salah satu contohnya.

\section{Frasa "Promo Kartini" dalam iklan 'Promo Medika Hospital' (Data 2 Aspek Gramatikal)}

Data tersebut merupakan keambiguitasan aspek gramatikal yang berbentuk frasa dalam sebuah iklan yang ditemukan di media cetak Balipost. Data tersebut dikatakan berbentuk frasa dikarenakan susunan kata tersebut terdiri atas dua kata dan tidak ditemukan predikat didalamnya, susunan kata tersebut disebut sebagai frasa dikarenakan sesuai dengan yang tertulis dalam KBBI bahwa, frasa merupakan gabungan dua kata yang bersifat nonpredikatif. Selain itu tidak ditemukan tanda baca yang menyertai susunan kata tersebut.

Makna yang terkandung dalam frasa tersebut adalah "Promo Kartini" yang berarti pelaksanaan promo pada hari kartini, dan "Promo Kartini" yang berarti Promo bagi masyarakat yang bernama Kartini. Frasa tersebut tergolong kedalam frasa yang ambigu dikarenakan frasa tersebut hanya berdiri sendiri tanpa disertai kalimat penjelas frasa tersebut.

Selanjutnya, keambiguitasan aspek gramatikal bentuk kalimat. Keambiguitasan bentuk kalimat terjadi akibat dari penggunaan kata atau frasa yang tidak tepat didalamnya. Selain itu, kurangnya ejaan juga dapat memengaruhi timbulnya keambiguitasan aspek gramatikal, hal ini sejalan dengan yang dinyatakan oleh Yusmawati dan Permana (2018) menyatakan bahwa, beberapa penyebab timbulnya ambiguitas dalam suatu kata atau kalimat disebabkan oleh kurangnya penanda ejaan, kesalahan letak suatu unsur dalam kalimat, serta pemilihan kata yang kurang sepadan dengan teks bahasa sumber. Kata atau frasa yang tidak tidak tepat maksudnya kata atau frasa tersebut telah dikenai atau telah ditetapkan sebagai kata atau frasa yang ambigu yang kemudian pemaknaanya dapat membingungkan pembaca, hal ini sejalan dengan yang dinyatakan oleh Djajasudarma (2012: 99) yang menyatakan bahwa setiap kata dapat bermakna lebih dari satu. Berdasarkan makna tersebut maka dapat disimpulkan bahwa kata yang tergolong sebagai kata yang ambigu dapat menjadikan kalimat yang disertainya menjadi ambigu juga. Untuk memperjelasnya, berikut adalah salah satu contoh kalimat yang merupakan kalimat yang ambigu yang ditemukan dalam iklan komersial media cetak Balipost.

\section{Kalimat "Tangki Air Bebas Kuras" dalam iklan Mpoin (Tangki Air dan Kimia) (Data 4 Aspek Gramatikal)}

Makna yang terkandung dalam kalimat tersebut adalah "Tangki Air Bebas Kuras" yang berarti tangki air yang berukuran besar sehingga dapat dikuras dengan lebih mudah, makna selanjutnya adalah "Tangki Air Bebas Kuras" yang berarti tangki air yang mengandung bahan-bahan 
kimia sehingga tangki tersebut tidak perlu dikuras karena telah terdapat bahan kimia didalamnya sehingga air tetap jernih.

Keambiguitasan dalam kalimat tersebut disebabkan oleh kemunculan frasa yang tergolong sebagai frasa yang ambigu didalam kalimat tersebut. Frasa tersebut adalah "Bebas Kuras" yang memiliki dua makna yakni "tidak perlu dikuras" dan "bisa dikuras". Kemunculan frasa tersebut dalam kalimat menjadikan kalimat tersebut ambigu.

\section{PENUTUP}

Dalam media cetak Balipost ditemukan cukup banyak iklan yang kata, maupun kalimatnya mengandung keambiguitasan. Keambiguitasan tersebut paling banyak ditemukan dari segi gramatikal, atau dari segi frasa maupun kalimat. Keambiguitasan yang ditemukan dalam media cetak tersebut tentunya akan memengaruhi representasi pembaca media cetak tersebut, dikarenakan informasi yang akan diterima oleh masyarakat melalui iklan menjadi tidak akurat. Untuk mengatasi hal tersebut, maka penting adanya jika pihak media cetak Balipost memilah berbagai iklan yang masuk dan tidak menerima iklan yang memiliki ketidakjelasan informasi atau iklan yang ambigu, sehingga informasi yang diterima oleh masyarakat menjadi jelas dan bermanfaat.

\section{DAFTAR PUSTAKA}

Chaer, A. 2015. Morfologi Bahasa Indonesia: pendekatan proses. Jakarta: Rineka Cipta Djajasudarma, T. F. 1993. Semantik 1 Makna Leksikal dan Gramatikal. Bandung: PT Refika Aditama Djajasudarma, T. Fatimah. 2012. Semantik 1: Makna Leksikal dan Gramatikal. Bandung: PT Refika Aditama.

Girsang, Lasmery. RM (2017). Pengukuran Efektivitas Iklan (Studi Komparasi: Iklan Media Cetak Dan Iklan Media Online). Commed: Jurnal Komunikasi dan Media, 1(2), 68-86.

Masrukhi, M. (2016). Iklan Komersial Media Cetak: Tinjauan Teks Dan Konteks. Jurnal CMES, 9(2), 125-136.

NASIKI, S. R. (2015). Ambiguitas Makna Pada Bahasa Iklan Di Harian Gorontalo Post. Skripsi, 1(311409014).

Oktavianti, M. (2019). Ambiguitas Pada Slogan Iklan Keluarga Berencana, Good Day, Tea Jus, Sariwangi, Floridina, Tolak Angin, Bukalapak, Dan One Push Vape.

Sugiyono. 2012. Memahami Penelitian Kualitatif. Bandung: Alvabeta

Swaryputri, I. G. A. L., \& Kapiresi, T. A. (2020). Persepsi Mahasiswa Terhadap Rubrik "Artikel Opini” Pada Surat Kabar Bali Post. Jurnal Kajian Ilmu Komunikasi, 20(1), 52-58.

Trismanto, T. (2018). Ambiguitas Dalam Bahasa Indonesia. Bangun Rekaprima: Majalah Ilmiah Pengembangan Rekayasa, Sosial dan Humaniora, 4(1, April), 42-48.

Wijana, D. P. dan M. R. (2008). SEMATIK: Teori dan Analisis. Surakarta: Yuma Pustaka

Yusmawati, Y., \& Permana, R. (2018). Makna Ambiguitas Pesan Pemberdayaan Masyarakat (Studi Kasus: Kampanye Sosial "Ketimbang Ngemis" di Media Sosial). LUGAS Jurnal Komunikasi, 2(2), 51-58. 